\title{
Analisis Pola Spekel Akusto-Optik untuk Pendeteksian Vibrasi Akustik pada Dental Plaque Biofilm
}

\author{
Harmadi* \\ Departemen Fisika, FMIPA Universitas Andalas, Padang 25163 \\ Gatut Yudoyono dan Agus Rubiyanto \\ Jurusan Fisika-FMIPA, Institut Teknologi Sepuluh Nopember \\ Kampus ITS Sukolilo, Surabaya 61111 \\ M. Zainuddin dan Suhariningsih \\ Program Pasca Sarjana, Universitas Airlangga \\ Jl. Darmawangsa Dalam Selatan, Surabaya 60286
}

\begin{abstract}
Intisari
Penelitian pendeteksian vibrasi akustik dari pola spekel pada sampel dental plaque biofilm yang merupakan studi in-vitro dental plaque biofilm telah dilakukan. Penelitian ini dengan menggunakan metode pencitraan akusto-optik, yaitu gabungan sistem akustik khususnya ultrasonik dengan sistem optik dalam satu perangkat, sehingga diperoleh pencitraan spekel. Pola spekel dianalisis menggunakan software imageJ akan diperoleh karakterisasi histogram distribusi intensitas gray level, dan didapatkan perubahan kontras spekel pada setiap pendeteksian vibrasi akustik oleh pengaruh frekuensi akustik dan pengamatan perubahan pembentukan sampel dental plaque biofilm. Untuk pengukuran ketebalan sampel, sebagai pembanding pengamatan kontras spekel digunakan CLSM yang dilengkapi AOTF. Diperoleh hasil pada sampel 2 jam dengan ketebalan $6 \mu \mathrm{m}$ memiliki kontras spekel tinggi sebesar 0.592707 a.u, pada sampel 4 jam dengan ketebalan $7 \mu$ m memiliki kontras spekel sebesar 0.571257 a.u, dan pada sampel 6 jam dengan ketebalan $9 \mu$ m memiliki kontras spekel rendah sebesar 0.550700 a.u. Terjadi perubahan pada sampel dental plaque yang diperoleh dari rongga mulut, mulai dari tahap pemasangan awal plaque biofilm, sampai dengan pembentukan plaque biofilm dewasa.
\end{abstract}

KATA KUNCI: pola spekel, akusto-optik, CLSM, dental plaque biofilm

\section{PENDAHULUAN}

Beberapa tahun terakhir ini, terjadi perkembangan yang luar biasa dalam bidang biofotonik. Biofotonik adalah suatu disiplin ilmu yang bertujuan untuk mengembangkan dan mengintegrasikan teknologi optik dengan bidang biologi, bioteknologi, biomedis, dan farmakologi [1]. Studi biofotonik memanfaatkan sifat-sifat istimewa foton (ruang dan waktu serta cakupan spektrum optik) dan interaksi optik dengan sistem biologis (radiasi, emisi, absorpsi, refleksi, refraksi, fluoresensi, diffusi, anisotropi). Sejalan dengan perkembangan biofotonik, berbagai teknik imaging (pencitraan) non-invasive (tanpa merusak) yang digunakan pada sistem biologi telah berkembang dalam beberapa tahun terakhir. Di antaranya yang paling baru adalah penggunaan metode akusto-optik pencitraan spekel (speckle imaging) untuk mendeteksi sinyal optik yang dihasilkan oleh sistem biologi [2-5].

Dari penelitian yang telah dikembangkan dengan menggunakan suatu sistem pencitraan akusto-optik terhadap me-

*E-MAIL: harmadimsi@yahoo.co.id dia atau jaringan biologi yang merupakan kontras citra optis dari jaringan, ternyata pola radiasi yang teramati adalah dalam bentuk pola spekel dari hamburan berkas laser yang secara serempak/bersama melewati medium sampel jaringan yang diberi gelombang ultrasonik [2]. Suatu studi analisis pencitraan spekel laser secara teori dan eksperimental dengan menggunakan continuous wave $(\mathrm{CW})$ dari laser He-Ne yang diterapkan dalam pencitraan ultrasonik telah dikembangkan dan digunakan sebagai titik awal untuk penjelasan spekel akustik [6]. Sistem pencitraan spekel laser mendeteksi perubahan intensitas spekel laser yang didifraksikan pada sampel dengan analisis kontras spekel [7-9]. Citra terbentuk sebagai kumpulan modulasi spekel yang ditangkap oleh CCD dengan pengaturan perekaman yang sesuai [9]. Di dalam beberapa penelitian, analisis kontras yang digunakan adalah analisis intensitas gray level (tingkat keabuan) dari hasil citra suatu sistem pencitraan spekel laser dengan menggunakan histogram yang digunakan untuk klasifikasi dan pencocokan pola [10]. Pencitraan optik dalam media atau jaringan biologi sangat diinginkan, karena menyediakan informasi kontras sangat sensitif yang memungkinkan pendeteksian potensi dini pengaruh ultrasonik pada jaringan [11]. Hal ini disebabkan sifat-sifat optis media atau jaringan biologi dalam daerah tampak dan inframerah-dekat dari spektrum elektromagnetik 
berhubungan dengan unsur pokok molekul dan struktur elektronik atau vibrasi dari jaringan. Pada hakekatnya pendeteksian sangat sensitif terhadap fungsi jaringan, dan dapat membedakan jaringan normal dengan jaringan tak-normal $[2,11]$.

Plak gigi merupakan contoh biofilm, dan sering disebut dengan dental plaque biofilm [12-15]. Dental plaque biofilm adalah lapisan licin terdiri dari protein, bakteri dan lendir terbentuk pada setiap lapisan permukaan keras dan padat yang berada di dalam mulut. Pertumbuhan dental plaque biofilm yang tidak terkendali dapat menimbulkan dampak besar berupa masalah kerusakan gigi, bahaya kesehatan, dan dapat menimbulkan infeksi [13]. Pengembangan penelitian ini diharapkan memberikan kegunaan untuk pendeteksian potensi dini (awal) secara fisik yang bergantung pada analisis modulasi optis dari pengaruh vibrasi akustik terhadap media dental plaque biofilm dalam bentuk analisis kontras spekel. Selanjutnya penelitian ini diharapkan dapat dikembangkan menjadi suatu peralatan untuk pendeteksian dan pengendalian dental plaque biofilm, dan dapat diterapkan untuk biofilm pada umumnya.

\section{MATERIAL DAN METODOLOGI}

Ketika berkas koheren dari laser dikenakan pada permukaan bahan, maka terbentuklah pola interferensi yang khas dalam bentuk suatu granular (butiran) bernama spekel [16]. Pola spekel merupakan pola distribusi intensitas dengan variasi acak yang teramati ketika berkas laser melalui obyek medium atau permukaan medium bahan, yang digunakan untuk mendapatkan informasi fisis tentang suatu bahan atau permukaan suatu bahan [5]. Medan cahaya pada suatu titik P di dalam ruang $(\mathrm{x}, \mathrm{y}, \mathrm{z})$ suatu pola spekel harus merupakan penjumlahan dari sejumlah besar $\mathrm{N}$ komponen, yang merupakan kontribusi dari semua titik pada permukaan hamburan [5]. Pada pencahayaan dengan menggunakan cahaya monokromatik dan cahaya terpolarisasi sepenuhnya, kontribusi untuk medan pada titik $P$ yang dihasilkan oleh berbagai elemen permukaan j, diberikan oleh :

$$
U_{j}(P)=\left|u_{j}\right| e^{i \phi_{j}}=\left|u_{j}\right| e^{i k r_{j}}
$$

$\mathrm{r}_{j}$ adalah jarak (variasi acak) dari elemen hamburan permukaan ke j pada titik P. Amplitudo kompleks dari medan hamburan pada titik $\mathrm{P}$ dapat ditulis sebagai

$$
\begin{aligned}
U(P) & =\frac{1}{\sqrt{N}} \sum_{j=1}^{N} u_{j}(P)=\frac{1}{\sqrt{N}} \sum_{j=1}^{N}\left|u_{j}\right| e^{i \phi_{j}} \\
& =\frac{1}{\sqrt{N}} \sum_{j=1}^{N}\left|u_{j}\right| e^{i k r_{j}}
\end{aligned}
$$

Penjumlahan dalam Pers. 2 dapat dianggap sebagai cara acak dalam bidang kompleks, dengan fase acak $\phi_{j}=k r_{j}$.

Goodman telah menunjukkan bahwa bagian riel dan imajiner dari medan resultan adalah asimtotik Gaussian $[17,18]$. Fungsi densitas probabilitas bersama diberikan oleh :

$$
p_{r, i}\left(U^{(r)}, U^{(i)}\right)=\frac{1}{2 \pi \sigma^{2}} \exp \left[\frac{\left(U^{(r)}\right)^{2}+\left(U^{(i)}\right)^{2}}{2 \sigma^{2}}\right]
$$

yang dikenal sebagai Circular Gaussian, dengan

$$
\sigma^{2}=\underbrace{\lim }_{N \rightarrow \infty} \sum_{j=1}^{N} \frac{\left\langle\left|u_{j}\right|\right\rangle^{2}}{2}
$$

Dari Pers.3, dan dengan mempertimbangkan bahwa intensitas I dan fase $\Phi$ medan resultan terkait dengan bagian riel dan imajiner dari medan sesuai dengan:

$$
\begin{aligned}
& U^{(r)}=\sqrt{I} \cos \Phi \\
& U^{(i)}=\sqrt{I} \sin \Phi
\end{aligned}
$$

Mengikuti bahwa densitas probabilitas dari intensitas p(I) dan probabilitas dari fase $\mathrm{p}(\Phi)$, diberikan oleh:

$$
\begin{aligned}
& p(I)=\frac{1}{\langle I\rangle} e^{-\frac{I}{\langle I\rangle}} \quad \text { untuk } I \geq 0 \\
& p(\Phi)=\frac{1}{2 \pi} \text { untuk }-\pi \leq \phi \leq \pi
\end{aligned}
$$

Secara berturut-turut di dalam Pers.6, $\langle I\rangle$ adalah nilai ratarata intensitas pada diagram spekel. Menurut dua persamaan terakhir tersebut, distribusi intensitas mengikuti hukum eksponensial negatif, sedangkan fase terdistribusi secara seragam dalam interval $(-\pi, \pi)$.

Distribusi intensitas beberapa saat didefinisikan sebagai:

$$
\left\langle I^{n}\right\rangle=n !\left(2 \sigma^{2}\right)^{n}=n !\langle I\rangle^{n}
$$

dan khusus pada saat orde kedua dinyatakan:

$$
\begin{aligned}
\left\langle I^{2}\right\rangle & =2\langle I\rangle^{2} \\
\sigma_{I}^{2} & =\left\langle I^{2}\right\rangle-\langle I\rangle^{2}=\langle I\rangle^{2}
\end{aligned}
$$

Persamaan ini menunjukkan bahwa standar deviasi dari pola spekel terpolarisasi sama dengan nilai rata-rata intensitas. Ukuran umum dari tingkat modulasi pola spekel disebut dengan kontras, yang didefinisikan sebagai :

$$
C=\frac{\sigma_{I}}{\langle I\rangle}
$$

dengan $\langle I\rangle$ adalah nilai rata-rata intensitas, $\sigma_{I}$ adalah standar deviasi dari intensitas, dan $\mathrm{C}$ adalah kontras spekel, dan ketika rasio (perbandingan) adalah 1 maka pola disebut memiliki kontras maksimum [5].

Untuk mendapatkan pola spekel, harus menggunakan konfigurasi difraksi dari suatu sistem optik [5]. Metode akustooptik adalah salah satu diantara sistem optik yang paling inovatif dan baru dengan cara mengkombinasikan akustik dan optik dalam satu perangkat, dimana difraksi merupakan prinsip kerjanya $[11,19,20]$, seperti yang diperlihatkan pada Gambar 1. Gambar ini merupakan susunan peralalatan yang digunakan untuk mengamati pola spekel dari vibrasi akustik pada sampel dental plaque biofilm, yang merupakan studi in-vitro dental plaque biofilm.

Sampel dental plaque biofilm yang diamati dikembangkan secara in-vitro pada media akrilik dan diambil langsung dari rongga mulut dengan perlakuan lama waktu pengambilan 2, 4, 


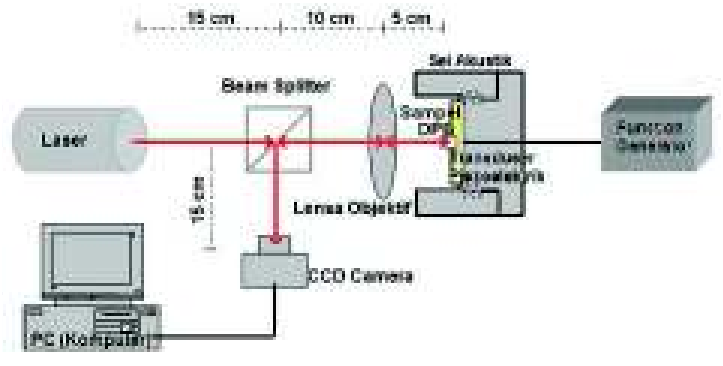

Gambar 1: Susunan peralatan pengujian sampel dental plaque biofilm (DPB) dengan metode akusto-optik pencitraan spekel.

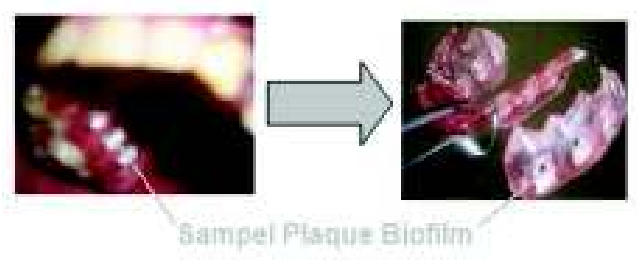

Gambar 2: Proses pengambilan sampel dental plaque biofilm.

dan 6 jam. Menurut Mohart dan Chandra [21, 22] setelah 2, 4, dan 6 jam sudah terbentuk dental plaque biofim, mulai dari monolayer hingga mikrokoloni mikroorganisme dalam bentuk dental plaque biofilm. Adapun proses pengambilan sampel dental plaque biofilm diperlihatkan pada Gambar 2.

Pengukuran dan pengamatan sampel dental plaque biofilm sebagai pembanding kontras spekel digunakan Confocal Laser Scanning Microscopy (CLSM) yang dilengkapi Acousto Optic Tunable Filters (AOTF), prinsipnya seperti terlihat pada diagram Gambar 3.

\section{HASIL DAN PEMBAHASAN}

Dari penelitian yang telah dilakukan, diperoleh bentuk pola spekel dari pencitraan spekel dengan metode akustooptik pada sampel dental plaque biofilm yang dikembangkan pada media dengan menggunakan bahan akrilik (poly methyl methacrylate (PMMA)) yang merupakan salah satu material dasar gigi tiruan lepasan [23, 24]. Data hasil pengamatan pola spekel dari citra sampel yang telah diperoleh, diproses dengan menggunakan software ImageJ untuk mendapatkan karakterisasi histogram distribusi intensitas tingkat keabuan pada kondisi sebelum digetarkan, saat digetarkan, dan setelah digetarkan seperti yang diperlihatkan pada Gambar 4.

Analisis secara statistik dengan menggunakan karakteristik histogram menampilkan distribusi intensitas tingkat keabuan citra yang bervariasi di setiap titik di dalam citra, sehingga dapat ditentukan nilai rerata intensitas $\langle I\rangle$ dan simpangan baku dari intensitas $\sigma_{I}$ yang merupakan ukuran variasi simpangan intensitas dari keseluruhan citra tersebut. Berdasarkan perolehan nilai rerata intensitas dan simpangan baku dari intensitas keseluruhan citra, maka dapat ditentukan kuantitas dari citra

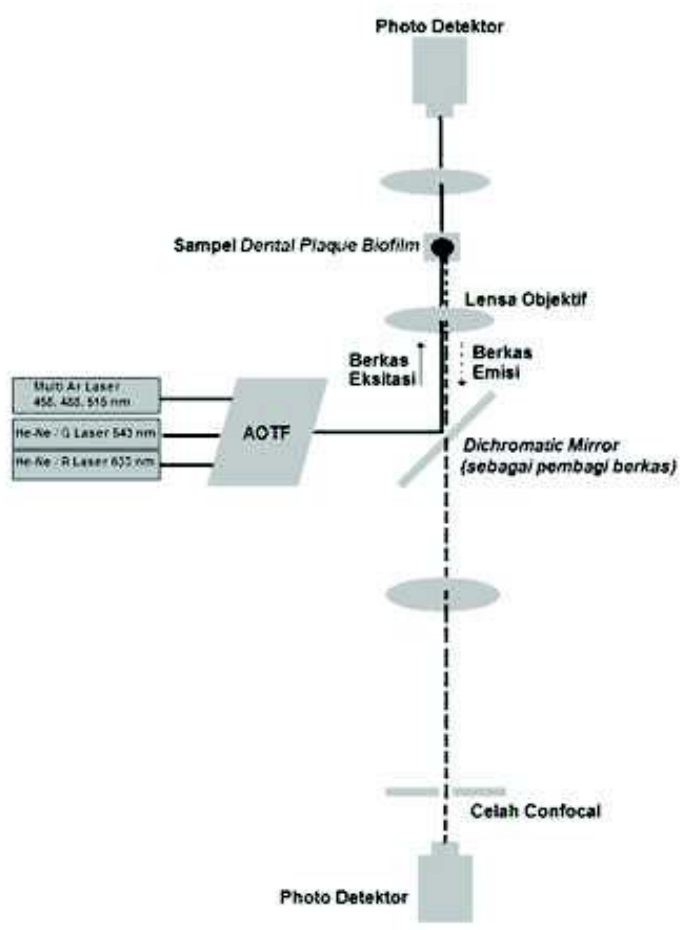

Gambar 3: Prinsip dari CLSM untuk pengujian sampel dental plaque biofilm.

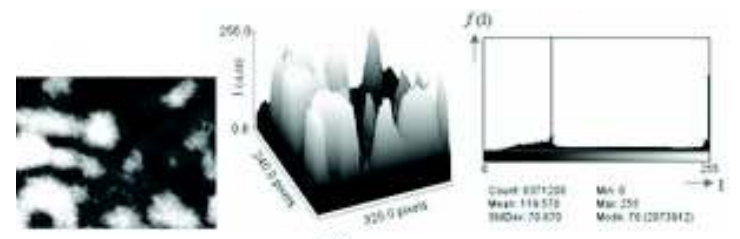

(a)

(a)Sebelum digetarkan $(0 \mathrm{~Hz})$
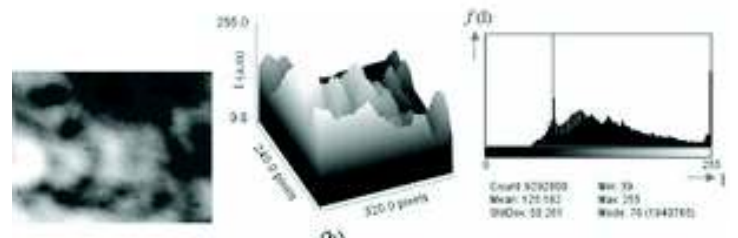

(b)

(b)Pada saat digetarkan dengan frekuensi $25 \mathrm{kHz}$

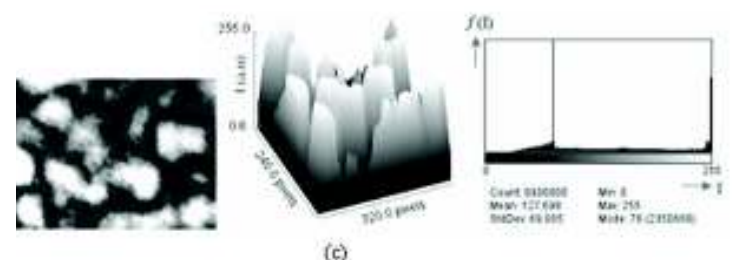

(c)Setelah digetarkan dengan frekuensi $25 \mathrm{kHz}$

Gambar 4: Bentuk perolehan karakteristik histogram dari pengolahan citra terhadap pola spekel pada sampel dental plaque biofilm. 


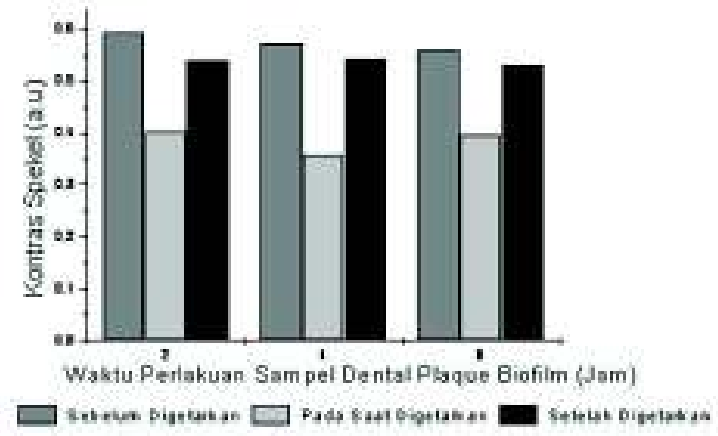

Gambar 5: Perubahan nilai kontras spekel pada sampel dental plaque biofilm akibat pengaruh vibrasi akustik frekuensi $25 \mathrm{kHz}$ pada kondisi sebelum digetarkan, saat digetarkan, dan setelah digetarkan.

dalam bentuk kontras spekel $\mathrm{C}$, yang merupakan rasio antara simpangan baku dari intensitas $\sigma_{I}$ dengan nilai rerata intensitas $\langle I\rangle$. Secara keseluruhan diperoleh perubahan nilai kuantitas citra pola spekel akusto-optik dalam bentuk kontras spekel pada sampel dental plaque biofilm dengan perlakuan 2, 4, dan 6 jam pada kondisi sebelum digetarkan dengan frekuensi akustik (0 Hz), pada saat digetarkan dengan frekuensi $25 \mathrm{kHz}$, dan setelah digetarkan dengan frekuensi $25 \mathrm{kHz}$, seperti yang ditampilkan pada Gambar 5.

Pada sampel dental laque biofilm terjadi perubahan nilai kontras spekel sebelum dan setelah digetarkan dengan frekuensi $25 \mathrm{kHz}$, dimana nilai kontras spekel setelah digetarkan mengalami penurunan dibandingkan dengan nilai kontras sebelum digetarkan.

Kontras spekel dapat digunakan untuk deteksi perubahan vibrasi akustik pada sampel dental plaque biofilm 2, 4, dan 6 jam oleh pengaruh frekuensi akustik pada rentang $0-50$ $\mathrm{kHz}$. Terdapat tiga daerah frekuensi akustik, yaitu dibawah frekuensi $16 \mathrm{~Hz}$ disebut dengan daerah infrasonik, frekuensi pada rentang $16-20.000 \mathrm{~Hz}$ disebut dengan daerah frekuensi sonik, dan frekuensi diatas $20 \mathrm{kHz}$ disebut dengan daerah frekuensi ultrasonik.

Pada daerah frekuensi infrasonik (seperti pada Gambar 6) terlihat kontras spekel semakin rendah seiring dengan meningkatnya frekuensi akustik pada setiap sampel dental plaque biofilm. Analisis modulasi spekel pada sampel terjadi penurunan kontras spekel, seiring dengan peningkatan frekuensi akustik. Efek dari frekuensi infrasonik ini akan mengenai sampel sehingga menyebabkan terjadinya resonansi (turut bergetarnya) setiap sampel dental plaque biofilm.

Pada daerah frekuensi sonik yaitu daerah yang termasuk frekuensi yang dapat didengar (audio-frequency), sampai dengan rentang frekuensi $1000 \mathrm{~Hz}$ (seperti pada Gambar 7) terlihat kontras spekel cendrung tetap atau konstan pada setiap sampel dental plaque biofilm. Analisis modulasi spekel pada sampel terlihat kontras spekel cenderung tetap, seiring dengan peningkatan frekuensi akustik sampai rentang $1000 \mathrm{~Hz}$.

Pada daerah frekuensi ultrasonik (frekuensi tinggi), memiliki daya tembus jaringan cukup besar. Terlihat pada Gambar 8, mulai dari frekuensi sonik yang ditingkatkan mendekati daerah ultrasonik sampai dengan rentang frekuensi $50 \mathrm{kHz}$

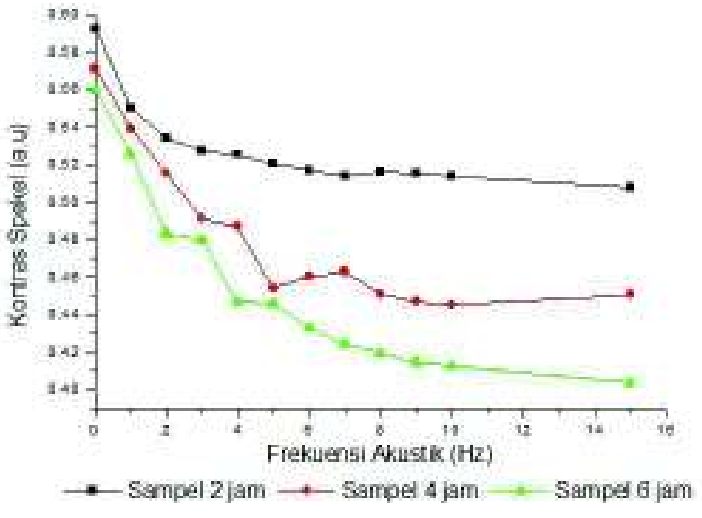

Gambar 6: Kontras spekel sampel dental plaque biofilm oleh pengaruh frekuensi akustik pada rentang $0-16 \mathrm{~Hz}$.

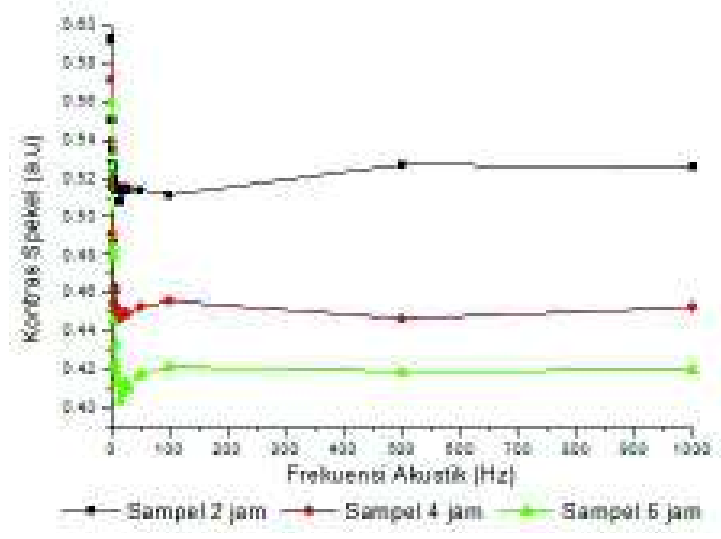

Gambar 7: Kontras spekel sampel dental plaque biofilm oleh pengaruh frekuensi akustik pada rentang sampai dengan $1000 \mathrm{~Hz}$.

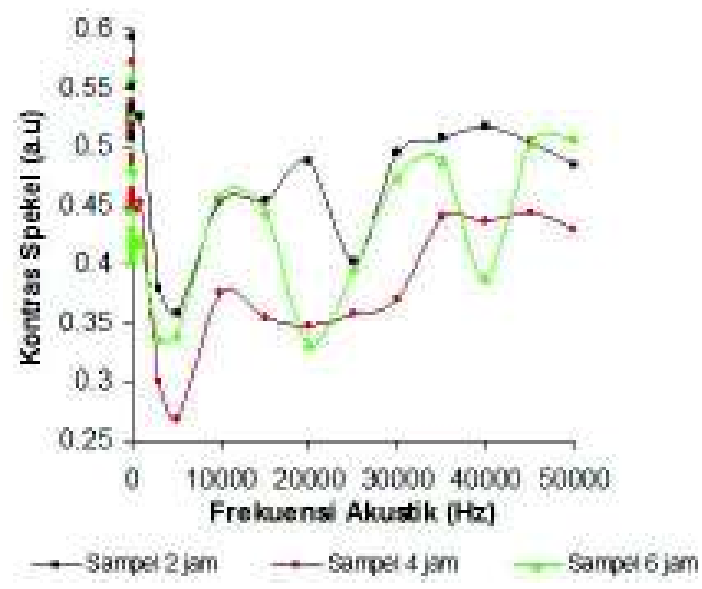

Gambar 8: Kontras spekel sampel dental plaque biofilm oleh pengaruh frekuensi akustik pada rentang sampai dengan $50 \mathrm{kHz}$. 

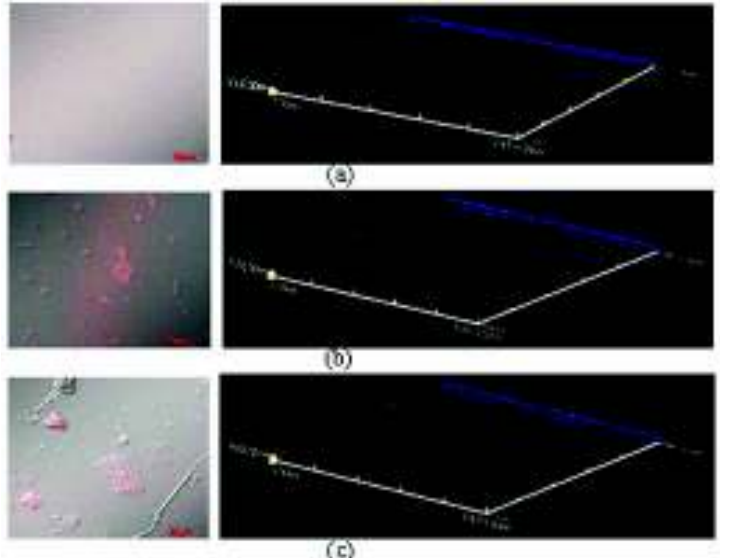

(c)

Gambar 9: Data tampilan pengamatan dan pengukuran ketebalan, sampel dental plaque biofilm pada perlakuan (a). 2 jam, (b). 4 jam, (c). 6 jam.

yang dikenai pada setiap sampel dental plaque biofilm, maka diperoleh kontras spekel yang tidak linier seiring dengan peningkatan frekuensi akustik, terjadi perubahan indeks bias secara periodik pada sampel.

Secara umum, efek akusto-optik yang dihasilkan oleh pembangkit gelombang ultrasonik yang merambat pada medium sampel, menyebabkan variasi periodik dalam indeks pembiasan. Terjadi osilasi amplitudo oleh frekuensi ultrasonik yang merambat melalui membran mikrokoloni mikroorganisme sampel dental plaque biofilm, di sekitar membran mikrokoloni timbul daerah rapatan dan regangan yang menyebabkan beda tekanan pada bidang batas sehingga terjadi tegangan di bidang batas tersebut. Makin tinggi frekuensi ultrasonik maka makin kecil panjang gelombang, sehingga makin pendek jarak rapatan dan regangan. Bila melampaui ambang tekanan pada mikrokoloni mikroorganisme maka membran dental plaque biofilm akan rusak sehingga memungkinkan mikroorganisme mengalami kematian (inaktivasi).

Aplikasi dengan CLSM, diperoleh data pengamatan dan pengukuran ketebalan sampel dental plaque biofilm pada perlakuan 2, 4, dan 6 jam, ditunjukkan pada Gambar 9.

Secara keseluruhan terjadi perubahan ketebalan pada sampel dental plaque biofilm 2, 4, dan 6 jam sebelum dan setelah vibrasi pada frekuensi $25 \mathrm{kHz}$ selama 3 sekon, ketebalannya mengalami kecendrungan semakin meningkat, seiring dengan makin meningkatnya waktu perlakuan sampel (Gambar 10).

Jika dikaitkan dengan pengamatan kontras spekel pada setiap sampel dental plaque biofilm akibat pengaruh vibrasi akustik pada frekuensi $25 \mathrm{kHz}$, maka terjadi perubahan kontras pada dental plaque biofilm. Pada sampel dental plaque biofilm setelah digetarkan mengalami penurunan kontras spekel jika dibandingkan dengan sebelum digetarkan.

Terlihat juga adanya perubahan pembentukan dental plaque biofilm, baik pada sampel perlakuan 2, 4, dan 6 jam. Setelah dilakukan pengukuran masing-masing sampel dental plaque biofilm, maka diperoleh ketebalan $6 \mu \mathrm{m}$ untuk sampel pada perlakuan 2 jam, $7 \mu \mathrm{m}$ pada sampel perlakuan 4 jam, dan

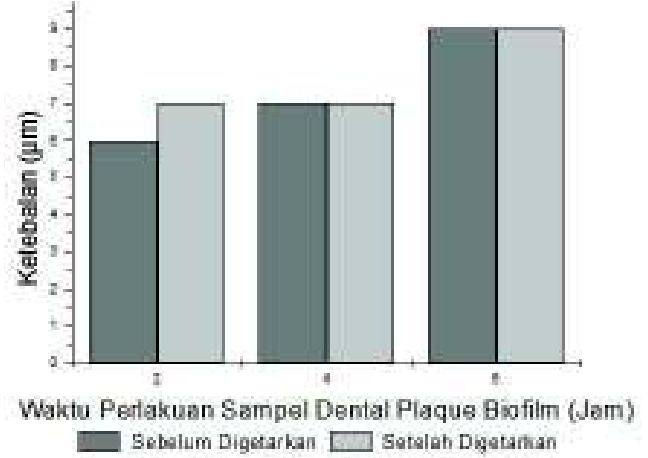

Gambar 10: Perubahan ketebalan pada sampel dental plaque biofilm 2, 4, dan 6 jam sebelum dan setelah digetarkan dengan frekuensi 25 kHz selama 3 sekon.

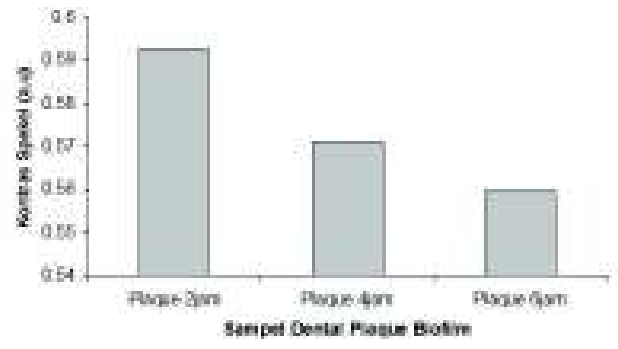

Gambar 11: Perbandingan kontras spekel terhadap sampel dental plaque biofilm 2, 4, dan 6 jam.

$9 \mu \mathrm{m}$ pada sampel perlakuan 6 jam. Jika dikaitkan dengan pengamatan masing-masing sampel dental plaque biofilm yang menggunakan kontras spekel sebelum dipengaruhi oleh frekuensi akustik, maka diperoleh perbandingan seperti yang diperlihatkan pada Gambar 11.

Makin lama waktu pembentukan dental plaque biofilm, maka kontras spekel makin rendah dan ketebalan sampel dental plaque biofilm meningkat. Sedangkan makin cepat pembentukan dental plaque biofilm, maka kontras spekel makin tinggi dan ketebalan sampel dental plaque biofilm menurun. Hal ini menunjukan terjadi perkembangan kehidupan pada sampel dental plaque biofilm yang diperoleh dari rongga mulut, yaitu mulai dari 2 jam tahap pemasangan awal dental plaque biofilm, sampai 4 jam dan 6 jam menuju ke pembentukan dental plaque biofilm dewasa.

\section{SIMPULAN}

Pencitraan spekel dalam bentuk pola spekel dapat dihasilkan dengan menggunakan metode akusto-optik konfigurasi difraksi pada sampel dental plaque biofilm 2, 4, dan 6 jam yang dikembangkan pada media akrilik. Analisis modulasi pola spekel dengan menggunakan pengolahan citra (histogram) menghasilkan kontras spekel, dapat digunakan untuk 
pendeteksian perubahan bentuk dental plaque biofilm akibat pengaruh vibrasi akustik. Akibat pemberian vibrasi akustik pada frekuensi $25 \mathrm{kHz}$ selama 3 sekon, terjadi perubahan kontras spekel pada dental plaque biofilm. Pada sampel dental plaque biofilm setelah digetarkan mengalami penurunan kontras spekel jika dibandingkan dengan sebelum digetarkan.
Semakin singkat waktu pembentukan dental plaque biofilm, maka kontras spekel makin tinggi dan ketebalan sampel dental plaque biofilm rendah. Semakin lama waktu pembentukan dental plaque biofilm, maka kontras spekel makin rendah dan ketebalan sampel dental plaque biofilm tinggi.
[1] Leveque F.S., Karine S., Pascaline L., Francis T., and MariePiere F-A., Imag. Anal. Diag., 70-77 (2003).

[2] Selb J., Leveque F.S., Lionel P., and Boccara A.C., Appl. Phys. Biophys. C. R. Acad. Sci. Paris, t.2, serie IV, p.1213-1225 (2001).

[3] Leveque F.S., Juliette S., Lionel P., and Albert C.B., Opt. Comm., 196, 127-131 (2001).

[4] Forget B-C., Francois R., Michael A., Juliette S., and Albert C.B., Appl.Opt.OCIS, Vol. 42, No.7 : 1379-1383 (2003).

[5] Rabal H. J., and Braga R.A., Dynamic Laser Speckle and Applications, Optical science and engineering,(Taylor \& Francis Group, LLC, 2009.)

[6] Abbott J.G., and Thurstone F.L., Acoustic Speckle: Theory and Experimental Analysis, (Ultra. Imag., 1 : 303-324, 1979).

[7] Tamaki, Araie, Kawamoto, Eguchi, and Fujii, Invest. Opt. Mol. Vis. Sci. 35, pp 3825-34 (1994).

[8] Vo-Dinh T., Biomedical Photonics Handbook, (CRC Press, New York, 2003).

[9] Li Nan, Tong S., Ye D., Shun, and Thakor, Cortical Vascular Blood Flow Pattern by Laser Speckle Imaging, Biomedical Engnineering Departement, Jhons Hopkins School of Medicine, Baltimore, 2005.

[10] Apsari R., Sistem Fuzzy Berbasis Laser Speckle Imaging Untuk Deteksi Kualitas Enamel Gigi Akibat Paparan Laser ND:YAG, Disertasi Program Pascasarjana UNAIR, Surabaya, 2009.

[11] Wang L.V., Ultrasound-mediated Biophotonic Imaging: A review of Acousto-Optical Tomography and Photo-Acoustic Tomography, (IOS Press,123-138, 2004).
[12] Gurenlian JoAnn R., J. Dent. Hyg., Special Supplement (2007).

[13] Cense A.W., A Spray Based Method for Biofilm Removal, Technische Universiteit Eindhoven, Eindhoven, 2005.

[14] Nield-Gehrig J.S., and Willmann D.E., Dental plaque biofilms $\therefore$ Foundations of Periodontics for the Dental Hygienist, (Lippincott Williams \& Wilkins : 67-73, 2003).

[15] Overman P.R., J. Contemp. Dent. Pract., Vol. 1, No. 3 Summer Issue (2000).

[16] Goodman J.W., Speckle Phenomena in Optic; Theory and Application, (Robert and Co., Englewood, Colorado, 2007).

[17] Goodman J.W., J. Opt. Soc. Am., 66, 1145 (1976).

[18] Goodman J.W., Statistical Properties of Laser Speckle Patterns, in Laser Speckle and Related Phenomena, 2nd ed., (Dainty, J.C., Ed., Springer Verlag, New York, 1984).

[19] Chivukula V.S., Michael S.S, and Daumantas C., Review Article Phys. Stat. Sol. (a) 204 No.10 : 3209-3236 (2007).

[20] Gies D.T., and Poon T-C., SECon. Proc. IEEE, 441-445, 2002.

[21] Morhart R., Cowman R., and Fitzgerald R., Ecologic Determinants of the Oral Microbiota, (In L. Menaker, Ed., The Biologic Basis of Dental Caries, Harper \& Row, Hagerstown, 1980).

[22] Chandra J., Mukherjee P.K., Leidich S.D., Faddoul F.F., Hoyer L.L., Douglas L.J., and Ghannoum M.A., J. Dent. Res., 80 : 903 (2001).

[23] Manappallil J.J., Basic Dental Materials, (Jaypee Brothers Medical Publisher (P) Ltd, New Delhi, 2008).

[24] Anusavice K.J., Buku Ajar Ilmu Bahan Kedokteran Gigi, (Alih Bahasa Budiman J.A., Purwoko S., EGC, Jakarta, 2003). 